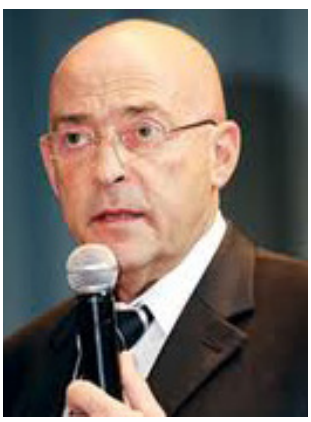

\author{
L. Markin, O. Besedin, K. Isayeva \\ Danylo Halytskyi Lviv National Medical University
}

\title{
Features of Giving Aid to Pregnant Women with Uterine Leiomyoma
}

Introduction. In recent years, one of the most current issues of modern obstetric and gynecological practice remains the problem of uterine leiomyoma in women of reproductive age. Nowadays, it occurs in $40.0-60.0 \%$ of cases $[8,12,13]$. Consequently, the combination of pregnancy and this pathology has been increased by 20.0 $\%$. The number of elderly primigravidas aged over 30 years has also a tendency to increase.

According to numerous studies, the presence of uterine leiomyoma is associated with the high risk of obstetric and perinatal complications [4, 6-10]. A series of studies, both national and foreign authors, are dedicated to the search for modern treatment methods of this condition in pregnant women. Unfortunately, many issues remain unsolved and controversial, especially regarding the surgical treatment of pregnant women with the presence of indicated pathology; there are no generally accepted standards for pregnancy and delivery of these patients.

Different degrees of developmental risk of obstetric and perinatal complications are determined by women's age exacerbated by hereditary, obstetric, gynecological and somatic anamnesis; localization, tumor size; severity of pathological changes in the uterus and systemic changes in the body caused by the development of tumor process $[1,2,4,11]$.

The complicated course of pregnancy in women with uterine leiomyoma occurs in approximately 10.0 to 40.0 $\%$ of cases $[5,12]$. Obstetric complications as threatened miscarriage, preterm labor, premature detachment of a normally located placenta, late gestosis, breech presentation and malposition may occur during pregnancy. There are also possible fetal complications: fetal growth retardation syndrome (FGRS), antenatal death, distress.

The incidence of premature detachment of the normally located placenta and breech presentation in pregnant women with leiomyoma in the uterus is 4 times higher, bleeding in the first trimester of pregnancy is 2 times higher, the risk of Cesarean section is higher in 6 times, and the risk of antenatal fetal death increases in 2 times according to systematic examinations and retrospective analyzes $[4,8,10]$.

As the influence is mutual, complications regarding to leiomyomatous nodes can include rapid tumor growth, torsion of the pedunculated node, node necrosis and prolongation of the acute stage of the necrotic process, foci contamination, rupture of the vessels nourishing uterine leiomyoma, pinching uterine fibroids in small pelvis. Large sizes of leiomyomatous nodes may also violate further development of pregnancy and the fetus, cause functional disturbances of adjacent organs and thrombosis (in continuous compression) of pelvic veins.

Obstetricians and gynecologists are faced with lots of issues diagnosing pregnancy in the background of uterine leiomyoma. Thus, the question is to interrupt or to prolong pregnancy? May conservative treatment versus surgery be conducted in case of complications? Is it expedient to conduct an elective operative intervention or just in case of urgent indications?

Currently, the problem of uterine leiomyoma and pregnancy is often solved to maintain the latter, considering the success of surgical treatment in obstetrics and the presence of modern drugs.

Leiomyomectomy should be the operation of choice due to complications regarding leiomyomatous nodes in modern obstetrics. Views on this issue remain controversial even today. A number of researchers point out that leiomyomectomy is the most often contraindicated in pregnancy, excluding special cases: enucleation of interstitial nodes of large sizes may cause uncontrolled bleeding, trauma of the amniotic membranes, inevitable miscarriage and preterm labor, interstitial hematoma formation, purulent septic complications; hysterectomy $[1,6,9,12,13]$.

In general, complicated uterine leiomyoma and the presence of large leiomyoma or its rapid growth which impedes further development of the fetus and disrupts functions of vital organs except acute necrotic changes in the node are indications for leiomyomectomy during pregnancy. Previously, necrosis of the leiomyomatous 
nodes was considered as an absolute indication for surgical intervention. Nowadays, the tactic is conservative and requirement for surgery is in $6.0-7.0 \%$ of cases $[5,9,10$, 12].

Data, conducting enucleation of leiomyomatous nodes in atypical and interstitial their localization with favorable completion of pregnancy, have been described in scientific studies of recent years. Many prospective and retrospective studies point out that planned leiomyomectomy is considered to be a safe option during pregnancy performed at the beginning of carefully selected patients as preventive procedure prior to acute complications $[9,10,12,13]$. In such cases the purpose of surgery is to preserve the uterus and the fetus. In urgent cases, surgical intervention is conducted at any gestation period in order to save woman's life. Nowadays, there are data about successful leiomyomectomy of huge, symptomatic leiomyomas with subserous and intramural location of nodes as alternative to abortion in the first trimester of pregnancy $[5,10]$.

Thus, solution to the issue of giving aid to pregnant women with uterine leiomyoma is the priority task in obstetric and gynecological practice.

The aim of the study. To improve methods of conservative and surgical treatment of pregnant women with uterine leiomyoma in case of the complicated pregnancy course due to accomplish maternal and perinatal consequences.

Materials and methods of research. 47 pregnant women with uterine leiomyoma underwent inpatient treatment due to complicated course of pregnancy at Lviv Regional Clinical Hospital during 2011-2017 and were under observation. The age of pregnant women was from 24 to $44(32.6 \pm 1.5)$. Elderly primiparae constituted 51.1 $\%$. In general, the complicated premorbid background was defined in $91.5 \%$ of pregnant women. The duration of the disease of the uterine leiomyoma was from 1 to 10 years. The term of pregnancy was in the range from 7 to 36 weeks $(20.3 \pm 1.2)$. Surgery was conducted in 20 $(42.6 \%)$ of these patients.

The analysis of complaints, anamnestic data, peculiarities of the course of pregnancy and its complications, indications for operation, the course of operation and postoperative period, pathological and anatomical conclusions, the condition of intrauterine fetus and a newborn were conducted to solve the tasks.

All women were subjected to dynamic clinical laboratory and instrumental examination. Particular attention was paid to palpation, indicators of general clinical blood tests, coagulogram, C-reactive protein (CRP) and ultrasound with dopplerometry in order to detect complications regarding leiomyomatous nodes. The condition of the fetus and a newborn was evaluated due to ultrasonography, dopplerometry, cardiotocography, biophysical profile and Apgar score.

Etiopathogenetic complex treatment including preventive and curative measures and surgical interventions aimed at reducing maternal and perinatal complications, preservation of pregnancy and reproductive function was conducted to pregnant women with uterine leiomyoma, considering pathogenetic aspects of pregnancy complications. Duration of treatment, the method of drugs administration, and their dosage were determined individually due to the clinical picture.

Destructive changes in the leiomyomatous nodes may occur in any period of pregnancy. These complications are associated with significant changes of local hormonal homeostasis, increased tone of hypertrophic smooth muscle fibers of contact myometrium, the imbalance between the size of the node and features of its blood supply, disorders of hemostasis. The main role in the occurrence of threatened miscarriage plays identical factors - the increased tone of hypertrophic smooth muscle fibers of contact myometrium with the subsequent development of spontaneous contractile activity, especially with progesterone deficiency in addition to premorbid background accompanying pregnancy. Nevertheless, alterative changes in leiomyomatous nodes, especially endothelial vessels damage, are the significant pathogenetic mechanism in the development of hypertension syndrome and hypercoagulation in the form of DIC syndrome in gestosis [1, 2, 11, 13].

Thus, the requirement to influence the tone of the myometrium, its significant relaxation and the improvement of microcirculation in the node becomes obvious. Therefore, spasmolytic, tocolytic, antiplatelet drugs, venotonics, and metabolic drugs were administered. Antibacterial drugs (cephalosporin group) were used in case of tachycardia, increased body temperature, and leukocytosis. The use of micronized progesterone was highly effective giving the opportunity to eliminate pain syndrome quickly, to transform the acute stage of necrosis into a subacute stage with its elimination in 10-12 days.

As it would subsequently cause the development of septic state and peritonitis, surgery was performed in the absence of the effect of conservative therapy for 3-5 days: increased pain syndrome, leukocytosis, and significant increase of fibrinogen level, CRP, ESR and evident clinical signs of prolongation of the acute stage of necrosis or foci contamination.

Prevention of respiratory distress of the fetus was carried out according to the term of pregnancy.

The treatment was identical as rapid growth factors of the node are the same as the occurrence of necrotic changes. Surgery was performed in cases of rapid node growth, the presence of leiomyomatous nodes of large and huge sizes, the existence of abnormalities in the function of adjacent organs, or a threat to further development of pregnancy. According to literature data, large nodes are considered to be $5.0 \mathrm{~cm}$ in diameter; one group of authors call nodes more than $10 \mathrm{~cm}$ as huge ones, another -15.0$20.0 \mathrm{~cm}$ in diameter $[1,4]$.

Urgent surgery was performed due to the clinical picture of "acute abdomen".

It should be noted that leiomyomectomy has its own peculiarities during pregnancy. It is related to the presence of extended vascularisation, high risk of increased blood loss, and thorough scar formation on the uterus.

Therapy (tocolytic drugs, metabolic drugs, micronized progesterone), aimed at prolonging pregnancy and improving fetoplacental flow, was administered preparing for surgery. 
Tocolytic drugs also improve fetoplacental flow, and micronized progesterone enables to reduce their doses and the period of application [3].

Leiomyomectomy in pregnant women was conducted under endotracheal anesthesia, which provides the best relaxation, minimal traumatic and optimal oxygenation for the fetus. Certain conditions of surgical tactics were adhered. The operation was started as the lower median laparotomy, the incision was of sufficient length for careful removal of the uterus in order to provide the most favorable conditions for the fetus, and to optimize access to atypically located leiomyomatous nodes. The uterus was carefully (if necessary) taken from the wound, did not fix, and enclosed with gauze wipes moistened in warm isotonic solution of sodium chloride. The incision on the uterus was selected considering the further abdominal delivery. Leiomyomatous nodes were removed by a sharp and dull way with the simultaneous application of clamps to all vessels in myometrium. Removing only large nodes, which hindered further development of pregnancy, was considered significant. Removing all nodes creates unfavorable conditions for postoperative period.

The choice of suture material and the method of applying sutures to the uterus play an essential role in creating favorable conditions for the formation of a complete scar and prevention of severe postoperative complications. Advantages were given to synthetic suture material with slow absorption characteristics (vikryl N $0, \mathrm{~N} 1$ ). Continuous stitches were overlapped in two or three rows. Thorough hemostasis, sanation and drainage of the abdominal cavity were conducted for 2-3 days. Modern antifibrinolytic drug (tranexamic acid) was used to reduce blood loss and reliable hemostasis.

Infusion therapy, aimed at restoring the volume of circulating blood, improving the microcirculation and the function of the intestine, was administered for 2-3 days after surgical intervention. Antibacterial therapy (cephalosporins) was given in order to prevent septic complications. The therapy, aimed at prolonging pregnancy, was continued. Metabolic and antiaggregant therapy with iron supplements was administered both to improve fetoplacental flow and to prevent thromboembolic complications.

Pregnant women, who had had leiomyomectomy during pregnancy, were subjected to dynamic monitoring with thorough control of postoperative scar on the uterus and the fetus. Planned hospitalization took place in the term of 35-36 weeks of pregnancy with the aim to prepare for delivery by Caesarean section.

The treatment was administered in accordance with the existing protocols of orders of the Ministry of Health of Ukraine in case of other pregnancy complications (FGRS, late gestosis, threatened miscarriage and preterm labor, breech presentation and malposition, etc.).

Delivery was conducted both through natural birth canal and by Cesarean section. Woman's age, obstetric and somatic anamnesis, the nature and localization of leiomyomatous nodes, the course of pregnancy, and the condition of the fetus were considered in solving the issue of delivery. Newborns' condition was evaluated at birth (by the Apgar score), during hospital stay and before discharge home. All women are given recommendations for further follow-up.

Statistical analysis was done using standard programs STATISTICA 6.0 and Microsoft Excel.

Results of the study and their discussion. Disorders of the reproductive function were observed in $78.7 \%$ of pregnant women. Primary infertility was in 14 women $(29.8 \%)$, secondary - in 7 women $(14.8 \%)$. The total number of pregnancies was 46 cases, 19 pregnancies (41.3\%) completed by spontaneous abortions. Missed miscarriages happened in 6 cases $(13.0 \%)$, ectopic pregnancies - in 5 cases $(10.9 \%)$. Deliveries occurred in 16 cases $(34.8 \%)$.

All examined women had various pregnancy complications. Threatened miscarriage and preterm labor were the most frequent complications and observed in 44 cases $(93.6 \%)$. Threatened miscarriage occurred more often in elderly primiparae $(54.5 \%)$. First half of pregnancy was accompanied by threatened miscarriage in $45.5 \%$, both first and second halves - in $54.5 \%$. Late gestosis occurred in 28 women $(59.6 \%)$, moderate course was in 7 women $(25.0 \%)$ and severe course had 2 women (7.1\%). Dystrophic changes combined with alternative hemorrhagic changes in 39.2 $\%$ of cases (necrosis, hemorrhages, vascular thrombosis, and inflammation) were revealed in further morphological study of leiomyomatous nodes in women. FGRS was diagnosed in 10 pregnant women $(21.3 \%)$; I degree of FGRS was found in 7 cases; II degree - in 3 patients. Abnormal positions and breech presentation occurred in 7 pregnant women (14.8\%). Transverse position of the fetus on the background of multiple uterine leiomyoma in combination with placenta previa was found in one patient. Anemia of pregnant women was diagnosed in 11 patients (23.4\%) as complications of the pregnancy course (fig.).

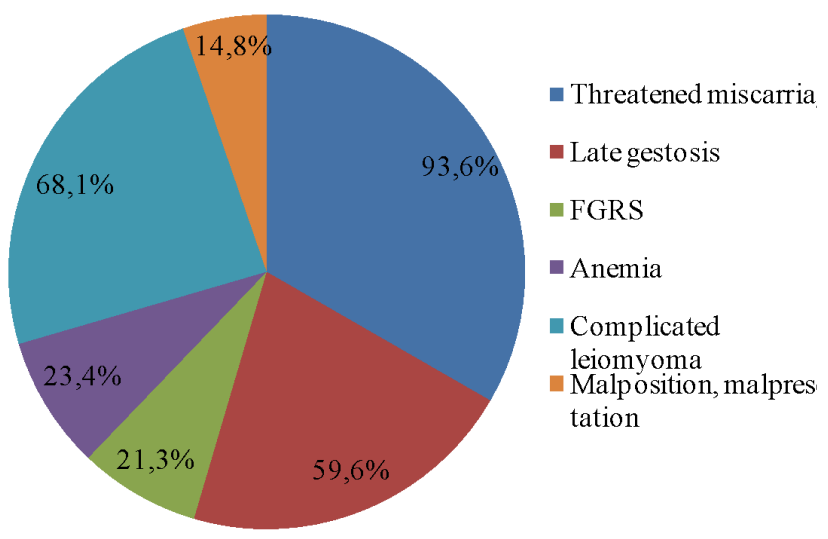

Main complications of pregnancy in patients with presence of uterine leiomyoma.

Following complications mainly happened on the background of subserous interstitial and interstitial leiomyomatous nodes $(76.6 \%)$ of large and huge sizes $(68.2 \%)$, and multiple uterine leiomyomas $(68.2 \%)$. 
Complications regarded to leiomyomatous nodes were marked in $32(68.1 \%)$ of pregnant women, corresponding to the diagnosis of complicated uterine leiomyoma during hospitalization to obstetric inpatient department. The presence of pain syndrome and elevated uterine tone was observed in $17(53.1 \%)$ of patients. Subfibrile body temperature $(28.1 \%)$ and slight tachycardia $(31.2 \%)$ were also present. Ultrasound showed an increase of leiomyomatous nodes and the presence of destructive secondary changes. Changes in laboratory parameters were determined by the increased ESR, total number of leukocytes and rod nuclear cells, fibrinogen level and CRP. Surgery was conducted due to prolongation of acute stage of necrotic process in large leiomyomatous nodes in 5 cases.

Another 12 (37.5\%) of pregnant women were referred to the hospital with signs of "acute abdomen"; one woman had signs of intra-abdominal bleeding. Thus, the urgent operation was conducted; necrosis of leiomyomatous nodes of huge and large sizes was diagnosed in 7 women, torsion of pedunculated subserosal nodes with their necrotizing was revealed in 4 cases, and the rupture of omental vessels which formed splicing to the secondary changed leiomyomatous node of huge sizes happened in one case.

Another surgery was performed to the pregnant woman with elevated signs of intestinal obstruction and compression of internal organs due to huge sizes of leiomyomatous nodes. In two cases surgery was conducted due to subserous interstitial, interstitial nodes of large and huge sizes hindering further development of the fetus and pregnancy (table).

\section{Main indications for surgical treatment in pregnant women} with leiomyoma of the uterus

\begin{tabular}{|l|c|c|}
\hline \multicolumn{1}{|c|}{ Indications } & $n=20$ & $n=20$ \\
\hline $\begin{array}{l}\text { Prolonged acute stage of necrotic } \\
\text { process in large leiomyomatous nodes }\end{array}$ & 12 & $60.0 \%$ \\
\hline Intraperitoneal bleeding & 1 & $5.0 \%$ \\
\hline $\begin{array}{l}\text { Torsion of pedunculated leiomyoma } \\
\text { with their necrotizing }\end{array}$ & 4 & $20.0 \%$ \\
\hline $\begin{array}{l}\text { Enlarging leiomyoma that obstruct } \\
\text { further fetal development and } \\
\text { pregnancy }\end{array}$ & 3 & $15.0 \%$ \\
\hline
\end{tabular}

Leiomyomatous nodes were large and huge in sizes from 5.0 to $18.0 \mathrm{~cm}$ in 32 pregnant women. Uterine leiomyoma was multiple with subserous, interstitial and subserous interstitial localization of nodes in $75.0 \%$ of cases. Surgery was conducted in $20(42.6 \%)$ of pregnant women. The term of pregnancy ranged from 15 to 28 weeks $(20.3 \pm 1.2)$. First pregnancy was in 10 women (50.0\%).

Consequently, pregnant women with uterine leiomyoma are at high risk group of obstetric and perinatal complications. Prognostically unfavorable course of pregnancy was on the background of large and huge leiomyomatous nodes, multiple uterine leiomyomas particularly of the interstitial and subserous interstitial localization. Pregnancy had been prolonged using pathogenetically-based schemes of treatment in $26(55.3 \%)$ of pregnant women with uterine leiomyoma and complicated course of pregnancy; subsequent parturition through natural birth happened in $12(25.5 \%)$ of cases and Caesarean section was conducted in $14(29.8 \%)$ of cases due to atypical location of leiomyomatous nodes, large and huge sized nodes with secondary changes and combined signs. Premature deliveries occurred in two pregnant women in the term 32 and 33 weeks; premature rupture of membranes was observed in the term of 28 weeks. Unfortunately, spontaneous abortion occurred in one pregnant woman in the term of 18-weeks.

Leiomyomectomy of large and huge nodes was usually conducted to pregnant women in all cases. The duration of operation constituted $80.21 \pm 10.02$ minutes in average; blood loss was $450.25 \pm 30.24 \mathrm{ml}$. Such complications as uncontrolled bleeding, trauma of the amniotic membranes during the operation and formation of interstitial hematoma, purulent septic conditions in the postoperative period were not noted at any case. Threatened miscarriage and threatened preterm labor symptoms were observed in $85.0 \%$ of cases during postoperative period and were therapeutically corrected. In one case the postoperative period was complicated by preterm labor in the term of 23 weeks and postoperative paresis of the intestine was observed in one pregnant woman operated due to the compression of the internal organs. Parturition of 14 women was conducted by Caesarean section in the term of 35-38 weeks and another 5 pregnant women are under observation.

In two cases, hysterectomy was conducted during Cesarean section due to uterine atony - in elderly primipara who was operated during pregnancy due to the increased signs of intestinal obstruction and compression of internal organs by huge-sized nodes and in elderly primipara in combination of multiple uterine leiomyomas and placenta previa. There were no surgical and postoperative complications in other cases.

Apparently, the relevant operating techniques, tactics, post-operative care, preventive and therapeutic measures allow avoiding many intra- and postoperative complications.

Pregnancies have been completed by the birth of living newborns in $40(95.2 \%)$ of cases out of 42 women. Satisfactory condition was marked in $26(65.0 \%)$ of newborns by the V. Apgar score. Newborns with mild asphyxia constituted $10(25.0 \%)$ cases, infants with moderate severity - $3(7.5 \%)$ cases and there was an infant with a severe condition due to prematurity.

Conclusions. Apparently, many pregnant women with uterine leiomyoma have the only chance to accomplish reproductive function. As pregnancy and uterine leiomyoma significantly aggravate the course of each other; medical aid should be directed to pre-gravida training and prevention of possible complications. The use of pathogenetically substantiated therapeutic and preventive measures allows improving maternal and perinatal consequences in the complicated course of pregnancy. Positive results were observed in the course of urgent 
surgery subjected to certain conditions when the risk of complications is always higher. So, it is essential to use elective surgical treatment. Leiomyomectomy should be a choice option for pregnant women, which allows prolonging pregnancy and maintaining the reproductive function.
This problem remains relevant and requires further randomized controlled trials to provide the most reliable data and to create regulatory framework with the aim to optimize the tactics of conducting pregnant women with this pathology despite the significant progress in improving diagnostic and treatment methods of uterine leiomyoma.

\section{References}

1. Кулаков ВИ, Шмаков ГС. Миомэктомия и беременность. М.: МЕДпресс-информ; 2001. 344 c. (Kulakov VI, Shmakov GS. Myomectomy and Pregnancy. M., 2001. 344 p.) (Russian).

2. Савицкий ГА, Савицкий АГ. Миома матки (проблемы патогенеза и патогенетической терапии). СПб: ЭЛБИ-СПб; 2000. 236 c. (Savytsky GA, Savytsky AG. Uterine myoma (problems of pathogenesis and pathogenetic therapy). StP, 2000. 236 p.) (Russian).

3. Шнайдер А, Марченко ЛА, Давидова ЮВ. Утрожестан: эффективное и безопасное сохранение беременности на ранних и поздних сроках. 3 турботою про жінку. 2012;1(31):4-5 (Shneider A, Marchenko LA, Davidova YuV. Z Turbotoyu pro Zhinku. 2012;1(31):4-5) (Russian).

4. Ciavatinni A, Clemente N, Delli Carpini G, Giuseppe Di. Number and size of uterine fibroids and obstetric outcomes. J Matern Fetal Neonatal Med. 201528(4):484-488.

5. De Carolis S, Fatigante G, Ferrazzani S, Trivellini C, De Santis L, Mancuso S et al. Uterine Myomectomy in Pregnant Women. Fetal Diagn Ther. 2001;16(2):116-19. https://doi.org/10.1159/000053893

6. Ezzedine D, Norwitz ER. Are Women With Uterine Fibroids at Increased Risk for Adverse Pregnancy Outcome. Clin Obstet Gynecol. 2016;59(1):119-127. https://doi.org/10.1097/GRF.0000000000000169

7. Fujii S. Uterine leiomyoma: pathogenesis and treatment. Nihon Sanka Fujinka Gakkai Zasshi. 1992;44(8):994-999.

8. Klatsky PC, Tran ND, Caughey AB. Fibroids and reproductive outcomes: a systematic literature review from conception to delivery. Am J Obstet Gynecol. 2008198(4):357-366. https://doi.org/10.1016/j.ajog.2007.12.039

9. Li TC, Mortimer R, Cooke LD. Myomectomy: a retrospective study to examine reproductive performance before and after surgery. Hum Reprod. 1999;14:1735-1740. https://doi.org/10.1093/humrep/14.7.1735

10. Mollica G, Pittini L, Minganti E, Perri G, Pansini F. Elective uterine myomectomy in pregnant women. Clin Exp Obstet Gynecol. 1996;23(3):168-172.

11. Pritts AE, Parker WH, Olive DL. Fibroids and infertility: an updated systematic review of the evidence. Fertil Steril. 2009;91(4):1215-1223. https://doi.org/10.1016/j.fertnstert.2008.01.051

12. Rothmund R, Taran FA, Boeer B, Wallwiner M, Abele Y, Campro R et al. Conservative Management of Symptomatic Leiomyomas during Pregnancy: a Retrospective Pilot Study. Ceburtshilfe Frauenheilkd. 2013;73(4):330-334. https://doi. org/10.1055/s-0032-1328437

13. Vitale SG, Tropea A., Rosetti D, Carnelli M. Management of uterine leiomyomas in pregnancy: review of literature. Updates Surg. 2013;5(3):179-182. https://doi.org/10.1007/s13304-013-0198-z

Стаття надійшла до редакції журналу 7 жовтня 2017 р.

\section{Особливості надання допомоги вагітним із лейоміомою матки}

\section{Л. Б. Маркін, О. В. Беседін, К. Ю. Ісасва}

Вступ. Упродовж останніх років однією з найактуальніших проблем сучасної акушерсько-гінекологічної практики є проблема лейоміоми матки у жінок репродуктивного віку, що трапляється у 40,0-60,0% випадків. Відповідно поєднання вагітності й цієї патології зросло до 20,0 \%.

Згідно з результатами численних досліджень, наявність лейоміоми матки асоціюється з високим ризиком акушерських і перинатальних ускладнень. Пошуку сучасних методів лікування цього захворювання у вагітних присвячена левова частка досліджень. Попри це, не з'ясовано багато питань, особливо щодо хірургічного лікування вагітних із цією патологією, немає загальновизнаних стандартів ведення вагітності та пологів у цього контингенту пацієнток.

Мета. Удосконалити методи консервативного та хірургічного лікування вагітних із лейоміомою матки при ускладненому перебігу вагітності з метою поліпшення материнських і перинатальних наслідків.

Матеріали й методи. Спостереженню підлягали 47 вагітних жінок із лейоміомою матки, які перебували на стаціонарному лікуванні $з$ приводу ускладненого перебігу вагітності у Львівській обласній клінічній лікарні впродовж 2011-2017 pp. Із них 20 (42,6 \%) пацієнткам проведено оперативне лікування.

Проаналізовано скарги, анамнестичні показники, особливості перебігу вагітності та їі ускладнень, показання до оперативного лікування, перебіг операцій та післяопераційний період, патологоанатомічні висновки, стан внутрішньоутробних плодів і новонароджених.

Вагітним із лейоміомою матки, із огляду на патогенетичні аспекти ускладнень вагітності, проводили етіопатогенетичне комплексне лікування (профілактично-лікувальні заходи та оперативне втручання, спрямоване на зниження материнських і перинатальних ускладнень, збереження вагітності та репродуктивної функції). Тривалість лікування, спосіб застосування препаратів, їх дозування визначали індивідуально, зважаючи на клінічну картину. 
Результати. 3'ясовано, що ускладнення вагітності виникли у всіх обстежуваних жінок без винятку. ЗПВ спостерігалась у 93,6 \% випадків, пізній гестоз - у 59,6 \%, СЗРП - у 21,3 \%, неправильне положення і тазове передлежання плода - у 14,8 \%. Ускладнення з боку лейоміоматозних вузлів діагностовано у 68,1 \% випадків.

Прогностично несприятливий перебіг вагітності зафіксовано на тлі великих і гігантських лейоміоматозних вузлів, множинної лейоміоми матки, особливо з субсерозно-інтерстиціальною та інтерстиціальною локалізацією. За умови застосування патогенетичнообгрунтованих схем лікуваня у $26(55,3 \%)$ вагітних із лейоміомою матки та ускладненим перебігом вагітності вдалося пролонгувати вагітність із подальшим розродженням через природні пологові шляхи у 12 (25,5 \%) випадках та операцією кесарського розтину в 14 (29,8 \%) випадках через атипове розташування лейоміоматозних вузлів, великих і гігантських розмірів вузлів із вторинними змінами, поєднаних показань. У однієї вагітної стався самовільний викидень у термін 18 тижнів.

Вагітним, які підлягали оперативному лікуванню, в усіх випадках проведено лейоміомектомію. У післяопераційному періоді спостерігались явища ЗПВ вагітності в 85,0 \% випадків, що було медикаментозно кориговано, лише в одному випадку післяопераційний період ускладнився передчасними пологами в термін 23 тижні. Розродження проводили операцією кесарського розтину в термін 35-38 тижнів у 15 жінок, ще 5 вагітних перебувають під спостереженням. Двом жінкам під час операції кесарського розтину проведено гістеректомію з приводу атонії матки. Зі 42 жінок вагітність завершиласянародженням живих дітей у 40 (95,2\%) випадках. Задовільний станзашкалоюАпгару 26(65,0\%) новонароджених.

Висновки. Вагітність і лейоміома матки суттєво обтяжують перебіг одна одної. За ускладненого перебігу вагітності застосування патогенетично обгрунтованих лікувально-профілактичних заходів дає змогу поліпшити материнські та перинатальні наслідки. Лейоміомектомія має бути операцією вибору у вагітних жінок, що дає змогу пролонгувати вагітність та зберегти репродуктивну функцію.

Незважаючи на значний прогрес в удосконаленні методів діагностики та лікування лейоміоми матки, ця проблема актуальна і вимагає подальшого проведення рандомізованих контрольованих випробувань з метою забезпечити найбільш достовірні дані та створення нормативної бази з метою оптимізації тактики ведення цього контингенту вагітних.

Ключові слова: вагітність, лейоміома матки, ускладнення, профілактично-лікувальні заходи, лейоміомектомія.

\section{Features of Giving Aid to Pregnant Women with Uterine Leiomyoma}

\section{Markin, O. Besedin, K. Isayeva}

Introduction. Nowadays, the combination of pregnancy and uterine leiomyoma has been increased by $20.0 \%$. The presence of uterine leiomyoma is associated with the high risk of obstetric and perinatal complications. A lot of studies are dedicated to the search for modern treatment methods. But many issues remain unsolved and controversial, especially regarding the surgical treatment of pregnant women with leiomyoma.

Aim. To improve the methods of conservative and surgical treatment of pregnant women with uterine leiomyoma in case of the complicated course of pregnancy due to accomplish maternal and perinatal consequences.

Materials and methods. 47 pregnant women with uterine leiomyoma underwent inpatient treatment due to the complicated course of pregnancy and were under observation. Surgery was conducted in $20(42.6 \%)$ among these patients. The analysis of complaints, anamnestic data, peculiarities of the pregnancy course and its complications, indications for operation, the course of operation and postoperative period, pathological and anatomical conclusions, the condition of the intrauterine fetus and a newborn were conducted to solve the tasks.

Results. Previous violation of reproductive function was observed in $78.7 \%$ of pregnant women. The term of pregnancy was in the range from 7 to 36 weeks. All examined women had various pregnancy complications. Threatened miscarriage and threatened preterm labor were in $93.6 \%$ of cases, late gestosis - in $59.6 \%$, FGRS - in $21.3 \%$, malposition, malpresentation - in $14.8 \%$, anemia of pregnant women - in $23.4 \%$ of cases. Complications regarded to leiomyomatous nodes were marked in $32(68.1 \%)$ of pregnant women, corresponding to the diagnosis of complicated uterine leiomyoma. Prognostically unfavorable course of pregnancy was in the background of large and huge leiomyomatous nodes, multiple uterine leiomyomas, particularly with interstitial and subserous interstitial localization.

Pregnancies were prolonged using pathogenetically-based schemes of treatment and surgical treatment in 45 of pregnant women with uterine leiomyoma and complicated course of pregnancy; subsequent parturition through natural birth happened in $12(25.5 \%)$ of cases and Caesarean section was conducted in $28(59.5 \%)$ of cases. Another 5 pregnant women are under observation. Pregnancies have been completed by the birth of living newborns in 40 (95.2\%) of cases.

Conclusions. Apparently, the relevant operating techniques, tactics, post-operative care, preventive and therapeutic measures allow avoiding many intra- and postoperative complications. Leiomyomectomy should be a choice option for pregnant women, which allows prolonging pregnancy and maintaining the reproductive function.

This problem remains relevant and requires further randomized controlled trials to provide the most reliable data and to create regulatory framework with the aim to optimize tactics of conducting pregnant women with this pathology despite the significant progress in improving diagnostic and treatment methods of uterine leiomyoma.

Keywords: pregnancy, uterine leiomyoma, complications, preventive and curative measures, leiomyomectomy. 